\title{
Corporate Governance Reforms in Nigeria: Challenges and Suggested Solutions
}

\author{
Ayodele Adelaja Adekoya \\ Yanbu Industrial College, Saudi Arabia
}

\begin{abstract}
This paper examines the challenges to corporate governance reforms in Nigeria from the promulgation of the Corporate and Allied Matters Act of 1990, the introduction of the 2003 Security and Exchange Commission (SEC) code of best practices in corporate governance to the 2006 Central Bank of Nigeria(CBN) code of corporate governance for banks in Nigeria. It uses related literature to review and discuss the identified challenges. It discovers that some of the challenges to corporate governance reforms in Nigeria stem from the country's culture of institutionalized corruption and political patronage which is characterized by weak regulatory frameworks and refusal of government agencies to enforce and monitor compliance. The complexity of these challenges are compounded by the wide spread poverty and high unemployment which discourages a culture of whistle blowing. A set of suggested solutions were made including the separation of business from politics, the establishment of a special corporate affairs tribunals within the judiciary to try violators, promoting the culture of whistle blowing, enhancing business through moral education and promoting resource based development through fiscal federalism.
\end{abstract}

\section{Keywords}

Corporate governance; corporate governance code; corporate governance environment; corporate governance mechanisms; regulatory framework.

\section{Introduction}

There has been renewed interest in corporate governance reforms in Nigeria amongst public and private sectors organizations (Alo, 2003; Wilson, 2006; Dabor and Adeyemi, 2009; Roe 2003; Ahmed 2007; Olusa, 2007), these practitioners and scholars have written on the benefits of good corporate governance in Nigeria but very few have drawn attention to the challenges posed by the inadequacy of the corporate governance mechanisms in Nigeria (Iyang, 2009; Wilson, 2006). Whilst Corporate governance might mean different things to different people, the Cadbury Committee's definition of corporate governance as "the system by which companies are directed and controlled" (Cadbury, 1992) provides a good basis for discussing the challenges of corporate governance reforms in Nigeria. The Organization for Economic Cooperation and Development's definition of corporate governance as "the structure through which company objectives are set and the means of attaining those objectives and monitoring performance" (OECD, 1999; 2004) highlights the importance of resolving the challenges of corporate governance reforms in Nigeria. Without good corporate governance, corporate

Copyright (C) 2011 Victoria University. This document has been published as part of the Journal of Business Systems, Governance and Ethics in both online and print formats. Educational and non-profit institutions are granted a nonexclusive licence to utilise this document in whole or in part for personal or classroom use without fee, provided that correct attribution and citation are made and this copyright statement is reproduced. Any other usage is prohibited without the express permission of the publisher. performance cannot be measured.

Corporate governance aims at promoting corporate transparency and accountability. Its goal is to enhance the directors' fiduciary duties and their ethical conduct in directing the affairs of a corporation but the recent happenings in most private corporations in Nigeria have raise concerns about the effectiveness of the corporate governance reforms in Nigeria. 
This paper sets out to discuss the challenges posed by the country's corporate governance reform mechanisms and to provide some insights into the possible solutions to the identified challenges especially regarding the newly introduced corporate governance codes by the Nigerian Security and Exchange Commission (SEC) and Central Bank of Nigeria (CBN).

The SEC inaugurated a code of best practices in corporate governance in 2003(SEC, 2003), three year later the CBN established another code of corporate governance for banks in Nigeria post consolidation in 2006 (CBN, 2006). These codes were invoked to supplement the Company and Allied Matters Decree (now an Act) of 1990 promulgated by a military administration to regulate all corporate affairs in Nigeria. Whilst both codes were aimed at promoting the tenets of good corporate governance which include transparency, accountability, responsibility, integrity, independence and discipline in the private sector corporations (Modlane, 2008). The Act remains the main law which regulates all corporate affairs in Nigeria. Despite all these legal and regulatory frameworks there have been shocking scandals in Nigerian organized private sector since the mid-1990s ranging from the failed and distress banks crisis of the late 1990s through the falsification of financial statements by Cadbury Nigeria Plc directors '(Olusa, 2007; Amao and Amaeshi, 2008) to the more recent sacking of the board of directors of eight banks for gross insider abuse and mismanagement of their banks' funds (Economic Confidential, 2009). These scandals indicate that there are challenges to the corporate governance reform mechanisms in Nigeria.

The focus of this paper is to answer these questions; are there challenges to the corporate governance reforms in Nigeria? If yes, what are these challenges? What are the possible solutions to these identified challenges? The paper is organized six sections; section one is the introduction while section two states the theoretical framework of the corporate governance concepts and terminologies. Section three uses related literature to discuss the evolution and challenges of the corporate governance reforms in Nigeria while section four identifies and classifies the major challenges to corporate governance reforms. The next section proffers possible solutions and the paper's final section provides the concluding remarks.

\section{Conceptual Framework}

\section{Corporate governance}

Corporate Governance is "the system through which corporations are directed and controlled" (Cadbury, 1992). It embodies the entire process for ensuring good corporate performance and responsiveness to shareholders and other stakeholders (Iyang, 2004). Given the importance of good corporate governance to a country's economic system and national development (Roe, 2003) many multilateral organizations such as the Organization of Economic Cooperation and Development (OECD, 1999; 2004), the Commonwealth Association of Corporate Governance (CAGG 1999), the World Bank (1999); the Global Corporate Governance Forum (GCGF, 1999); the Pan African Consultative Forum on Corporate Governance (PACFCG, 2001) have recommended corporate governance principles for corporations.

\section{Corporate governance code}

The most typical method for ensuring good corporate governance reforms in most countries is through the invocation of corporate governance codes which supplement existing corporate laws. Corporate governance codes are documents which state the rules and procedures for governing and managing corporations (Dabor and Adeyemi, 2009; Ugoji and Isele, 2009; Scott, 2007; Classens and Bruno, 2007). Since corporate governance is a process by which corporations are governed and controlled with a view to increasing shareholders values and meeting the expectations of other stakeholders (CBN, 2006; Iyang, 2009), the codes categorically state the rules, principles and best practices for governing corporations properly (Okhealam and Akinboade 2003; Armstrong 2003; Gatamah 2008; Andreason 2009). Most corporate governance codes are instituted by self regulating professional bodies with the consent of the relevant government regulating agencies but the responsibility for adopting and implementing the code lies on a corporation's board of directors (Elebute, 2000; Iyang, 2009; Sanusi 2003, Soludo 2004). Hence it has been argued that the boards major responsibility is to 
ensure good corporate performance, increase shareholders' value, protect stakeholders' interests, contribute to society's wellbeing, preserve the environment and to prepare accurate financial reports (Alo, 2003; Wilson, 2006; Dabor and Adeyemi, 2009; Roe 2003; Ahmed 2007; Olusa, 2007, Elebute, 2000; Iyang, 2009; Sanusi, 2003, Soludo, 2004).

\section{Corporate governance mechanism}

Corporate governance mechanisms are the processes and systems by which a country's company laws and corporate governance codes are enforced. The mechanisms incorporate the means for monitoring compliance by corporations (Reed, 2002). The effectiveness of a country's corporate governance mechanism depends largely on the country's regulatory frameworks and public governance systems (Wilson, 2006, Dabor and Adeyemi, 2009; Roe, 2003; Ahmed, 2007; Olusa, 2007). The corporate governance codes are best enforced by professional bodies in collaboration with government institutions and the capital market regulators or vice versa (Vinten, 2002; Reed, 2002; Wilson 2006; Roe, 2003). The existence of many corporate governance mechanisms does not necessarily translate into good corporate governance as many corporate scandals in Nigeria and other countries have proven. The wide-spread adoption of a country's corporate governance code by private sector corporations often indicate mere conformance which does not necessarily mean that the corporations are committing themselves to sound and ethical business practices (Rossouw, 2005, Gatamah, 2008; Iyang, 2009). A survey conducted by SEC in Nigeria indicates that 40 percent of country's quoted companies have adopted the corporate governance code (Amao and Amaeshi, 2008; Olusa 2007) but the incidences of lack of transparency, accountability, integrity, social responsibility and environmental sustainability have not abated.

\section{Corporate governance environment}

A country's corporate governance environment considers the impacts of the political, economic and social-cultural factors that enhance good corporate governance or prevent unethical conduct ( $\mathrm{Li}$ and Nair, 2009). It embodies the political, economic, social, technological and legal institutions that influence the ethical dispositions of private corporations (Amaeshi and Amao 2008; Wilson, 2006). The Corporate governance environment determines the context for evaluation a corporations' performances, decisions, strategic choices and actions. While the political, cultural and socioeconomic ramifications of the recently introduced corporate governance codes in Nigeria are still being studied, it is important to note that these codes were established as instruments for safeguarding the corporations against corruption, mismanagement and environmental abuse. These codes were invoked to promote corporate transparency and accountability, economic growth and social development (Okhealam and Akinboade, 2003; Armstrong, 2003; Gatamah, 2008; Andreason, 2009).

Prior to the introduction of Nigeria's foremost corporate governance code by the SEC in 2003, the country's corporate governance reform mechanism were enforced via military decrees most notably was the Corporate and Allied Matter Decree (CAMD) now Corporate and Allied Matters Act (CAMA) of 1990 when the country returned to civilian rule in 1999. This law regulates and governs all corporate matters relating to corporations and non-profit organizations in Nigeria. Given that the CAMA was military promulgated decree, there were insufficient stakeholders' inputs and lack of parliamentary debates into the law making process. Nonetheless, the CAMA was able to address some of the lapses and loopholes observed in the 1968 Company's Act. The CAMA sets up the Corporate Affairs Commission (CAC). The CAC has wider powers and more authorities that the defunct company registrar which it replaced; it supervises, regulates and resolves all corporations' related matter in Nigeria. the SEC corporate governance code was later introduced in 2003 was to supplement the effectiveness of the CAMA (Amaeshi and Amao ,2008; Wilson, 2006; Amao, 2002) just as the CBN code was meant to supplement the effectiveness of the Bank and Other Financial Institutions Act of 1992 .

\section{Related literature}

Corporate governance is an evolving field which have gained popularity in the last decade after the demise of Enron, Worldcom, Arthur Anderson etc in the United States which have forced academics, 
legal practitioners, accounting and other professionals, regulatory agencies, government institutions, NGOs and international financial institutions to pay attention to corporate governance reforms, (Kay and Silberston 1995; Vinten, 1998; 2002; Aquiler and Luervo- caruza, 2004; Bhasa, 2004; Mardjono, 2005; Wieland, 2005; Chambers, 2006; Malin, 2008; Judge, Douglas and Kutan, 2008; De Cleyn, 2008). Other Countries have had similar corporate scandals, for example HIH Insurance in Australia; Marconi in UK, Parmalat in Italy; Regal Bank, Leisure Net and Krion in South Africa and Cadbury PLC in Nigeria. Consequent upon these publicized corporal scandals and the preceding financial crises experienced in Asia in the late 1990s, there was a global impetus to promote good corporate governance, accountability and ethical business practices in many countries (Alo 2001, Sanusi, 2003; Wilson, 2006; Iyang, 2009). Thus, many multilateral organizations such as the Organization of Economic Cooperation and Development, the Commonwealth Association of Corporate Governance, the United Nations Compact instituted principles and best practices of corporate governance which corporations and countries are encouraged to adopt and practice (OECD, 1999; 2004; CAGG, 1999; UN Compact, 2002).

Corporate governance codes are documents which state the principle, rules and procedures for making strategic decisions and prescribe the frameworks for governing corporations and achieving corporate objectives (Ajogwu, 2009; Alo, 2001). Corporate governance is a system by which organizations and company are directed, managed and controlled in order to enhance corporate performance and cater for shareholders concerns and stakeholders interests (Sanusi, 2003; Iyang, 2004). Corporate governance has a leadership dimension, because it provide directional leadership to organizations by creating an enabling environment which integrates and systematize various collaborative efforts for setting objectives and achieving corporate goals (Ugoji and Isele, 2009). Good corporate governance helps to prioritizes organizational objectives achieve good corporate performace, enhances ethical decision making within organizations where shareholders' concerns and stakeholders interest and are addressed properly (Sanda, Mikailu and Garba, 2005; Wieland, 2005; Chambers, 2006; Malin, 2008; King, 2006; Andreasson 2009; Vinten 1998; 2002; Aquiler and Luervo- caruza, 2004; Gatamah 2008, Roe, 2003; De Cleyn 2008).

The triple bottom line reporting introduced by Elkington (1997) and adopted by the Kings Report, (IoDSA, 2002; 2009) requires modern corporations to disclose their economic, social and environmental performances instead for better decision making. The Social Responsible Investment index adopted by South Africa's (JSE, 2004) requires quoted corporations in South Africa to integrate social responsibility and environmental sustainability issues into their corporate strategic plans and to adopt sound business practices (Naidoo, 2002; Wixley and Everingham 2005; Vaughan and Ryan 2006; Taylor 2007; Roe, 2003). Corporations are vital part of the society and as corporate citizens, they are expected to contribute actively to the development of society and protect the natural environment (West, 2006; King, 2006).

It has been widely acknowledged that good corporate governance helps most developing countries and emerging markets to attract domestic and foreign direct investments, build their markets competitiveness, restore investor confidence, promote economic growth and boost national development (Armstrong, 2003; Koufopoulous, 2006; Okhehalam and Akinboabe 2003) but there are many challenges to ensuring good corporate governance in these developing countries ( $\mathrm{Li}$ and Flier, 2007; Wilson, 2006) especially when the corporations need to be convinced that they are not independent of the society, host community or the natural environment in which they operate (IoDSA, 2002; Rossouw, 2005; Ngwakwe, 2009). It has been affirmed that the mechanisms for ensuring good corporate governance exist in Nigeria but the will and capacity to enforce the laws, monitor and ensure compliance need to be strengthened because the CAC as the main agency for regulating and supervising all corporation related matters in Nigeria is weak and perfunctory in performing its duties (Oyejide and Soyibo, 2001; Okike 2007, Amaeshi et al, 2008).

In 2006, the CBN prescribed certain measures for mitigating the fifteen weaknesses that were observed in the 25 mega banks that emerged from the banking industry consolidation exercise of 2005 but the poor implementation and weak enforcement of the CBN corporate governance code have prevented the $\mathrm{CBN}$ from achieving its objectives of ensuring proper corporate governance in Nigerian banks. Three years after the CBN mandatory code was established, the boards of directors of eight 
banks in Nigeria were sacked for poor corporate governance, insider abuse and mismanagement of their shareholders and depositors funds (Next, 2009; Alli, 2009). Although these listed weaknesses were misconstrued as challenges (Wilson, 2006; Iyang, 2009) it was still expected that the CBN will be able to enforce its own code on the banks since it applies to just one section of the financial industry in Nigeria unlike the SEC Code that applies to the entire organized private sector. The CBN's failure to effectively eradicate these identified 'challenges' and to develop sound banking institutions in Nigeria implies that there are still many challenges to the corporate governance reform mechanisms in Nigeria. These challenges are embedded in the corporate governance environment and the weak enforcement mechanisms because events have shown that the CBN code was either not complied with completely by the banks or its enforcement deliberately compromised by the CBN, SEC and other regulating agencies.

At this point, it is necessary to separate the challenges from the weak internal control mechanism of individual corporations. While, the $\mathrm{CBN}$ may be overburdened as initiator of monetary policies, banker to other banks, financial industry regulator, monetary policy formulator, currency issuer, adviser to the federal government, and inter-bank settlement and payment system manager (Wilson 2006), it still has a duty to effectively monitor and enforce its corporate governance code on the banks (Iyang, 2009) as it has been rightly pointed out that the real challenges to corporate governance reforms in Nigeria are the weak, inefficient, inadequate legal, institutional and regulatory frameworks.

\section{Challenges to corporate governance reforms in Nigeria}

While there are laws and corporate governance codes for ensuring good corporate governance in Nigeria the major challenge lies in the weakened, inefficient and inadequate legal and regulatory frameworks for enforcing and monitoring compliance with the CAMA and the corporate governance codes in Nigeria (Amaeshi et al 2006, Wilson 2006; Okhehalam and Akinboabe, 2003; Nmehielle and Nwauche, 2004; Oyejide and Soyibo, 2001; Okike, 2007; Iyang 2009). To further buttress this point, just two months into the tenure of the new CBN governor, the CBN in August 2008 exercise its powers to comprehensively audit the 25 mega banks that emerged from the banking industry consolidation exercise. A year later, after the audit, only 15 banks (60 percent) were considered healthy, eight (32 percent) were distressed and two ( 8 percent) were grossly undercapitalized. The CBN had to sack the board of directors and ?sacked of the eight distressed bank for gross insider abuse and financial impropriety. The sacked directors are now being prosecuted for various financial crimes in Nigeria. The new CBN management was quick to admit that the CBN's failure to effectively enforce its own corporate governance code and monitor its strict compliance was partly responsible for the 2009 banking industry crisis as such the CBN had to quickly reorganized its banks supervision unit while embarking on a more extensive corporate governance reform in the Nigeria banking industry (Thisday, 2009; Sanusi, 2010).

The objective of this paper therefore is to identify the major challenges to corporate governance reforms and suggest some possible solutions. The assertion by Amaeshi et al (2006) that the Nigeria's legal enforcement and regulatory framework are weakened and made inefficient by institutionalized corruption has been widely accepted as the bane of poor corporate governance in Nigeria but this alone cannot be blamed for the persistent corporate governance failures in Nigeria. There are other socio-political, economic and cultural factors which create the dismal corporate governance environment in a country (Wilson, 2006; Meyer, 2006; Andreasson, 2009) and these factors are analyzed within the socio-political context of contemporary Nigeria in order to provide more detailed insights into the challenges to corporate governance reforms in Nigeria which are discussed in the subsequent paragraphs.

\section{Institutionalized corruption}

Corporations cannot be divorced from the corruption that exists in the society in which they are operating especially if they are operating in a weakened corporate governance environment like Nigeria (Wilson, 2006; Liu and Lin 2009). After attaining independence from Britain in 1960, Nigeria was ruled by unelected military governments for a total of thirty years while the remaining twenty has been under corrupt civilian elite. Under both systems, a culture of political patronage was fostered on 
the country by the ruling class; the military regimes institutionalized corruption and created an atmosphere of impunity from arrest and legal prosecution while the politicians shielded law breakers (who are politically connected) from investigations and prosecution (Amaeshi et al 2006; Bakre 2007; Elumelu 2007; Okuaru 2006). Since 1972 when the Nigerian Enterprises Promotion Decree as amended in 1977 and 1989 (otherwise known as the indigenization decree) was promulgated by a military administration to promote indigenous ownership of business (later repealed and replaced by the Nigerian Investment Promotion Act of 2000), the politicians and business owners have formed an alliance and both spheres have been dominated by the same ruling class (Afigbo, 1989). The politicians often appoint their cronies as board members of government agencies and use them to award bogus and over inflated contracts to private sector corporations in which they have controlling interest, influence or powers to extract bribes from. In other instances the private sector organization offer kickbacks to the politicians and helped them to launder their loot through legitimate corporate channels (Bakre, 2007; Elumelu, 2007; Okuaru, 2006).

This ignoble alliance between the political and business class has created a system where corruption is institutionalized and further entrenched through a network of family owned and controlled companies. 80 percent of the registered companies in Nigeria are small and medium scale enterprises (SMEs) which are family owned and controlled (Limbs and Forts 2000; Oyejide and Soyibo 2001; Ahunwan, 2002). The corruption is so pervasive such that the CAC cannot effectively monitor the SMEs. Even when the CAC wants to do so, the politicians and business owners who have appointed to the CAC Board members often frustrate such laudable efforts. Thus the SMEs are inclined to doing business with the politicians in the 'Nigerian way' because the politicians often influence how government contracts are awarded and how government officials are 'settled' through bribes and kickbacks. In a bid to stop this institutionalized corruption, the civilian government had to set up two special anticorruption agencies; the Independent Corrupt Practices Corruption (ICPC) and the Economic and Financial Crime Commission (EFCC) but the effectiveness of these agencies in fighting corruption is being influenced by the ruling politicians.

\section{Weak regulatory framework}

Nigeria is a country where the ruling elites have little respect for the laws of the land. Rather than obeying laws, the politicians will peddle their political influence and connections to circumvent and violate laid down procedures and control mechanisms. Nigeria operates a unique system where the ruling political elites are treated as 'untouchables' and 'above the law' (Emenyonu, 1996). The country's law enforcement agencies have been deliberately weakened by the corrupt practices of the political elites either military or civilian such that they are more inclined to look the other way instead of confronting the 'big men'. The institutionalized corruption discussed above is so entrenched that law enforcement is done alongside a culture of political patronage. The politicians siphon public funds and launder them through the corporations and use their political influence to prevent the law enforcement agencies from investigating their cronies (Dike, 2005; Bakre, 2007; Yinusa and Adeoye, 2006). It is these corrupt practices and abuse of official privileges that have made Transparency International to consistently list Nigeria as one of the most corrupt countries in the world (Ibru 2008; Amaeshi et al 2006; Bakre, 2007).

The Corporate governance mechanisms in Nigeria will always weak remain as long as the politicians and business owners are closely linked and are mutually dependent on each other for bribes and patronage. The politicians need the corporations and business professionals to launder their ill gotten wealth and to consolidate their hold on power (Bakre, 2007) and the business class need the politician for government contracts and patronage. The business owners also rely on the politicians for protection to avoid paying taxes and to avoid criminal investigation, arrest and subsequent prosecution for their corrupt practices and tax evasion (Okauru, 2006; Dike 2005; Nye, 1967).

\section{Wide spread poverty caused by high unemployment}

The third major challenge to corporate governance reforms in Nigeria is the wide spread poverty and high unemployment. Over 70 percent of the Nigerian population lives below the absolute poverty line of less than one U.S dollars per day and the country's unemployment rate is approximately 50 percent 
of the population (World Bank 2009). Thus, the incentives for doing business transparently, accountably and maintaining high ethical standards are nonexistent (Visser, 2006). Corporations in Nigeria often behave in manners that suggest that they are not bothered by the environment and social responsibility concerns of the citizens (Ngwakwe, 2009). Nigeria is a country where the government has persistently reneged on its many promises of rapid development promises to the people such that corporations are more inclined to disrespecting the people's rights, doing business unethically, damaging the natural environment than embarking on corporate social responsibility (Ite, 2004; 2005).

Due to the widespread poverty, whistle-blowing on unethical corporate practices or professional misconducts are not encouraged (Akosile, 2007; Komolafe, 2008). There are many cases where fraudulent acts have been reported to government agencies by employees, informed outsiders or even professionals but very little have resulted from it. Those who blew the whistle often become the victims of oppression instead of being protected and rewarded for their patriotic acts (Bakre, 2007; ICAN 2008).

\section{Collapse of moral values}

The fourth challenge to good corporate governance in Nigeria is the collapse of the country's moral values (Tukur, 1999). While Nigerians are seen to be very religious, with 90 percent of the population subscribing to one form of religion or the other (Yinusa and Adeoye, 2006), the lack of transparency and accountability especially amongst the religious leaders have made the religious institutions to become accomplices to the widespread corruption (Bello-Imam, 2004). The country is often described as a nation with no moral values or has lost its moral compass such that the religious institutions are more interested in material things rather than the spiritual development of the believers. The institutional and widespread corruption discussed above has eaten deep into the Nigerian society (Emenyonu, 2007; Tomori, 2010) such that some religious leaders who are accused of money laundering and other criminal acts are not investigated and brought to justice, Faith based organizations are consistently accused of financial impropriety at different times to the extent that the people seem to be losing their faith and confidence in these religious institutions. Moreover, most religious organizations do not have annual audited financial statements and do not submit their annual reports to the CAC. The situation is worse, when prominence is given to the corrupt politicians and business owners by the various religious leaders and institutions.

\section{Falling Standard of education}

The fifth challenge is the falling standard of education in Nigeria, the educational institutions which are supposed to inculcate the moral values of honesty; integrity and rectitude in young minds are bogged down by strikes, inefficient leadership, insufficient funding, low staff morale and rampant closures. The quality of education in Nigeria has declined steadily since the mid 1980s due to corruption, poor funding, rampant closures and industrial actions by staff union (Babalola, 2006). Eventually, the students will graduate without obtaining the optimum level of learning from institutions bedevilled by favoratism, cultism, examination malpractices or other vices only to join the expanding band wagon of unemployed youths who are seeking employment. Only few graduates are able to find employment and those who get employed do so through nepotism, the political patronage or business connections referred to above and they start their training in political intrigues and high stake corruption very early in their career due to poor business ethics in the public and private sectors (El-Rufai, 2003). The graduates observed their supervisors and manager breaking business rules, circumventing established procedures and avoiding internal control systems or ignoring code of conduct yet cannot blow the whistle for fear of losing their jobs. Before very long, they too get accustomed to these unethical conducts and corrupt practices which has been perpetrated by their mentors such that when they are promoted to senior positions they have become adept at breaking rules, cutting corners and adopting sharp practices (Saliu and Aremu 2004; Bello-Imam 2004). 


\section{Suggested possible solutions}

\section{Demarcating the boundary between business and government}

The first step to overcoming the corporate governance reform challenges in Nigeria is to demarcate the boundary between businesses and politics. This means that clearly separating the corporations from the government agencies that patronize them. The office of public procurement should prevent all political interferences in selecting bids for government contracts. There must be clear distinction between the political elites and the business owners. The existing policies that forbid political office holders and public servants from being directors in private sectors corporations should be enforced by the $\mathrm{CAC}$ and other relevant government agencies. If enforced properly, the inherent conflict of interests which leads to unethical decisions by corrupt government officials would be checked and this will make contract bidding more competitive. Unless these laws are enforced properly and equally to all without prejudice to personalities or political positions, Nigeria cannot have a good corporate governance environment (Wilson, 2006) and the present efforts at corporate governance reforms will surely come to naught.

\section{The establishment of a special corporate affairs tribunal}

The second step is to establish a special corporate affairs tribunal where violators of the CAMA are tried promptly and speedily. The present situation where violators are simply fined and allowed to remain in operations does not serve as enough deterrence to the violators. Prosecuting the offenders through the regular courts is not only time wasting (lasting between two and ten years) but also resource consuming as all kinds of legal injunctions are sought and obtained to delay and frustrate the trials.

Prior to the establishment of the special corporate affairs tribunal, the CAC must reorganize itself to enhance its monitoring and enforcement mechanisms so that violators are investigated and brought to justice quickly. The present situation when the country's corporate laws are breached with the active connivance of professionals especially lawyers; accountants and auditors without investigation and prosecution have created several avenues for breaking the law by unscrupulous persons (Bakre, 2007). The proposed corporate affairs tribunal should be a specialized court within the country's judicial system independent of the executive arm of government so that political influences are reduced to the barest minimum.

\section{Promoting the culture of whistle blowing}

This third step of promoting a culture of whistle blowing is dependent upon separating corporations from government which requires demarcating the boundary between business owners and political office holders discussed above. The CAC should set up a hotline when complaints can be lodged by employees or stakeholders who are aware of any violations. A culture of whistleblowing is encouraged when the signed complaints or anonymous petitions are properly investigated without disclosing the petitioner's identity. The EFCC and the ICPC have adopted this strategy to discourage corruption but this practice has not been extended to the private sector where most corporate law violations occur. If the CAC's monitoring and enforcement mechanisms are reorganized to carry out investigations, most complaints could be dealt with speedily and the business community will react appropriately. The culture of whistle blowing will be facilitated and allowed to thrive when the investigations and law enforcement are independent of political pressures and influences from the political office holders.

\section{Enhancing business ethics through moral education}

The fourth step is to instil moral values and enhancing business ethics through moral education in the youths. A nationwide programme where the citizens are inculcated with sound moral values and trainings at schools, universities, churches, mosques and cultural organizations is required. The essence of this moral education is to train the citizens that crime does not add value to a person's career and "the fear of God is the beginning of wisdom" (Holy Bible, Proverbs 9:10). This step requires more transparency and accountability from our religious institutions for them to inspire, 
maintain and sustain a culture of moral discipline and rectitude among our citizens (Zekeri, 2008; Emenyonu 2007). The efforts of the Non-Governmental Organizations (NGOs) such as the Zero Corruption Coalition and the Civil Society Legislative Coalition in fighting corruption should be intensified especially at the top where government officials are held responsible and accountable to the citizenry by the legislative arm of government.

\section{Facilitating rural development through employment generation}

At present, the country's macroeconomic policies are focused on job creation at the urban centres with limited infrastructural development and employment opportunities in the rural area. This centralization of resources and amenities in the cities breeds corruption and creates a poor corporate governance environment. A political solution to both menaces is to decentralize resources and promote employment generation at the local level through fiscal federalism such that development is resource driven and grassroots oriented as was the case in the 1960s. Nigerians should be allowed to develop from the rural area and hinterland through agriculture and other local resource-based employment activities rather than pursuing bogus contracts and other get rich quick schemes in the big cities and urban centres.

\section{Conclusion}

This paper discusses the challenges to corporate governance reforms in Nigeria after agreeing to the fact that the country's corporate laws and corporate governance codes as sufficient for promoting good corporate governance in Nigeria. It identifies the challenges as institutionalized corruption, weak regulatory framework, wide-spread poverty caused by high unemployment, collapse of the countries moral values and the falling standard of education. The paper suggested a set of possible solutions which include demarcating the boundaries between business and government, establishing a special corporate affairs tribunal in the judiciary to try offenders of the country's corporate laws, promoting a culture of whistle blowing, enhancing business ethics through moral education as well as facilitating rural development through resource based grass root employment opportunities. Before Nigeria can enjoy the benefits of good corporate governance the CAC must effectively enforce and monitor compliance by corporations and should be able to impose sanctions on offenders and violators without fear or prejudice in order to boost investors' confidence and public trust and make shareholders and other stakeholder feel protected from corporate exploitation and mismanagement (Nmehielle \& Nwauche 2004; Ahunwa, 2002; Ajogwu, 2007; Okike 2007, Iyang 2009).

\section{References}

Ahmed M. (2007) "Corporate Governance: a new fad or an important development prerequisite?" Paper presented at the British Council's Management Express Forum Calabar, Nigeria. http://www.triumphnewspapers.com/archive/DT02042007/crop25207.html

Afigbo, A. E. (1989) "Federal Character: its Meaning and History" in P.P. Ekeh and E. Osaghie (eds) Federal Character in Nigeria. Ibadan, Nigeria: Heinemann.

Aguilera, R.V. \& Cuervo - Cazurra, A. (2004) Code of good governance worldwide, what is the trigger? Organization Studies 25 (3) 415-443

Ahunwa B. (2002) Corporate Governance in Nigeria, Journal of Business Ethics 37, 269 - 286

Ajogwu F. (2007) Corporate Governance in Nigeria: Law and Practice, Lagos. Nigeria: Centre for Commercial Law Development

Alli Y. (2009) CBN sacks three more bank chiefs, directors. The Nation October 3, 2009.

Akosile, A. (2007) "Protecting the Whistle Blower" - Thisday August 282007.

Alo, O. (2003) Issues in Corporate Governance Financial Institution Training Centre. Lagos

Amao (2002) "Corporate Governance, Multi National Corporations and the law in Nigeria:

Controlling Multinationals in host State". Journal of African Law, 52:89-113 (2008)

Amao O. \& Amaeshi K. (2008) Galvanising shareholders activism: a prerequisite for effective corporate governance and accountability in Nigeria. Journal of Business Ethics 82: 119-130 
Amaeshi K. \& Amao O. (2008) Corporate Social Responsibility (CSR) in Transnational Spaces: An Institutionalist Deconstruction of MNC CSR Practices in the Nigeria Oil and Gas Sector, CSGR Working Paper 248/08.

Amaeshi, K., Adi, B. C., Ogechie, C. and Amao, O. O. (2006) Corporate Social Responsibility in Nigeria: Indigenous practices or Western influences? Journal of Corporate Citizenship (Winter edition) 24: 83-99

Andreasson, S (2009) Understanding Corporate Governance Reform in South Africa: AngloAmerican Divergence, The Kings report and Hybridization, Business \& Society http://bas.sagepub.com/cgi/rapidpdf/0007650309332205v1

Armstrong, P. (2003) Status report on corporate governance reform in Africa, paper Presented at the Pan Africa Consultative Forum on Corporate Governance

Aquiler, R.V. \& Cuerzo - Caruza, A. (2004) Codes of good governance worldwide, what is the trigger? Organisation Studies 25 (3) 415- 443

Babalola A. (2006) "The Dwindling Standard of Education in Nigeria: The way forward", First Distinguished Lecture Series, Lead University, Ibadan, Nigeria

Bakre O. (2007) Money Laundering and Trans-organised Financial Crime in Nigeria: Collaboration of the Local and Foreign Capitalist Elites WP 07/03 Department of Accounting and Finance, University of Essex, U.K.

Bello- Imam I. B. (2004) "Corruption and National Development" in Bello-Imama and Obadan I.M. Eds Democratic Governance and Development in Nigeria's fourth Republic 1999-2003. Ibadan CLGRDS

Bhasa M.P. (2004) Global Corporate Governance debates and Challenges, Corporate Governance 4 (2): 5-17.

Cadbury A. (1992) Report of the Committee on the Financial Aspect of Corporate Governance, London, U.K: Gee \& Co. Limited

Central Bank of Nigeria-CBN (2006) Code of Corporate Governance for Banks in Nigeria Post Consolidation.

Chambers R. (2006) Corporate Secrecy: The Final barrier to corporate governance, International Journal of Business, Government \& Ethics 43-53

Classens, S. \& Bruno, V.G. (2007) Corporate Governance and regulation: can there be too much of a good thing? Policy Research Working Paper 4140, March 2007, World Bank.

Commonwealth Association for Corporate Governance, (1999) CACG Guidelines: Principles for Corporate Governance in the Commonwealth; Marlborough, New Zealand.

Dabor, E. L. \& Adeyemi S.B. (2009) Corporate Governance and the Credibility of Financial Statements in Nigeria, Journal of Business Systems, Governance and Ethics; 4 (1) 13 - 24

De Cleyn, S.H. (2008) Compliance of companies with corporate governance codes: A case study of Listed Belgian SMEs, Journal of Business System, Governance and Ethics 3 (1), 1-16

Dike, V. E. (2005) Corruption in Nigeria: A New Paradigm for Effective Control, Africa Economic Analysis http://www.africaeconomicanalysis.org/articles/gen/corruptiondikehtm.html

EconomicConfidential - CBN Sacks 5 Bank CEOs, Injects N400bn and Refunds \$90mn to FAAC www.economicconfidential.com/sept09monetarysackboss.htm

Elebute K. (2000) Corporate Governance reporting and Shareholder value, Business and Management Journal 3 (1) $8-19$.

Elkington J. (1997) Cannibals with forks: The Triple Bottom line of the $21^{\text {st }}$ century Business. London: Capstone

El- Rufai (2003) "Is liberal democracy, encouraging corruption and corrupt practices", the Nigeria Social Scientist (6) 2 35- 56

Gatamah, K. (2008), "Corporate Governance in the African Context". Economic Reform Feature Service, 1-6 http://www.cipe.org/publications/fs/pdf/033108.pdf accessed $12^{\text {th }}$ February 2009

Emenyonu E.N. (2007), The Accounting Profession, the Church and the Nigerian State: Change agents for National Rebirth. Public Lecture given at the Covenant University Ota, Ogun State Nigeria on June 14, 2007

Global Corporate Governance Forum (1999) http://www.gcgf.org/ accessed $4^{\text {th }}$ February 2010

Holy Bible Proverbs Chapter 9 V 10 - Holy Bible (2004) Nashville, United States: Thomas Nelson Inc 
Ibru C. (2008) "The corporate Governance Question" - Paper presented at the roundtable for Proactive laws and Good Governance in Nigeria. International Conference Centre Abuja Nigeria

Institute of Chartered Accountants of Nigeria (2008) "Corruption a global problem"; a communiqué issued by the Institute of Chartered Accountants of Nigeria in Abuja. October 2008

Institute of Directors in Southern Africa (1994) Corporate Governance for South Africa

Institute of Directors in Southern Africa (2002) Executive Summary of the Kings Report on Corporate Governance for South Africa 2002. Johannesburg, South Africa.

Institute of Directors in Southern Africa (2002) Report on Corporate Governance for South Africa 2009. Johannesburg, South Africa.

Inyang B.J. (2004) Corporate Planning \& Policy: concepts and application. Calabar, Nigeria: Merb Publishers.

Inyang B.J. (2009) 'Nurturing Corporate Governance System: The Emerging Trends in Nigeria' Journal of Business Systems, Governance and Ethics; 4 (2) 1-13

Ite U.E. (2004) "Multi National Corporations \& Corporate Social Responsibility in Developing Countries": A Case Study of Nigeria. Corporate Social Responsibility and Environmental Management, 11 (1): 1-11

Ite U.E. (2005) U.E. (2005) "Poverty reduction in resource -rich developing countries: what have multi nationals got to do with it?" Journal of International Development 17(7) 913-929

Judge, W.Q., Douglas T.J. \& Kutan, A.M. (2008) 'Institutional antecedent of corporate governance legitimacy' Journal of Management 34(4) 765-785

Kay, J. \& Silberston, A. (1995) Corporate Governance, National Institute of Economic Review 153 (1) 84-107

King M. (2006) The Corporate Citizen: Corporate Governance for all entities. Johannesburg, South Africa: Penguin.

Komolafe B. (2008) "Corruption: ICAN call for Whistle Blowing Act; Reduced Regulation"

Li, S. \& Flier, L. (2007) "The effect of the governance environment on the choice of investment mode and the strategic implications" Journal of World Business 42 (1) 80-98

Li, S \& Nair A. (2007) 'A comparative Study of economic reforms in China and India: What can we learn?' Global Economic Review 36 (2) 147-166

Limbs, E.C. \& Fort, T (2000), 'Nigerian Business Practice and their interface with Virtue Ethics' Journal of Business Ethics 26:169-176

Liu, M. \& Lin Z. (2009). The determinants of auditors switch from the perspective of corporate governance in China. Corporate Governance: An International Review, 17:476-491

Malin, C. (2008) Institutional shareholders: Their role in the shaping of corporate governance, International Journal of Corporate Governance 1(1) 97-105

Mardjono A. (2005) A tale of corporate governance: lessons why firms fail, Managerial Auditing Journal 20(3) 272-283.

Mondlane A.A. (2009). Corporate Governance in Africa www.isbee.org/index.php?option=com docman\&task=doc...gid accessed $12^{\text {th }}$ February 2010

Meyer K. E. (2006) Asian management research needs more self-confidence. Asia Pacific Journal of Managemnt 23: 119- 137

Naidoo R. (2002) corporate governance: An Essential guide for South African companies. Cape Town, South Africa: Double story Books

Next (2009) CBN sacks CEO and Management of five Nigerian banks - August 14, 2009

Ngwakwe C.C. (2009). Environmental Responsibility and Firm Performance: Evidence from Nigeria. International Journal of Humanities and Social Sciences 3(2) Pp 97-103

Nmehielle, V.O. \& Nwauche E.S. (2004), External - Internal Standards in Corporate governance in Nigeria. Paper Presented at the Conference on Corporate Governance and Accountability in Sub Saharan Africa. The George Washington University Law School, Public Law and Legal Theory Working paper No. 115 October 29, 2004.

Organization for Economic Cooperation and Development (OECD) (1994), Principles of Corporate Governance, Paris: OECD Publication Services

Organization for Economic Cooperation and Development (OECD) (1999), Principles of Corporate Governance, Paris: OECD Publication Services. 
Ogbechie, C. \& Koufopoulous D.N. (2007) Corporate Governance Practices in publicly quoted companies in Nigeria, International Journal of Business Governance and Ethics 3 (4) 350-381

Okeahalam C.C. \& Akinboade O.A. (2003). A review of Corporate governance in Africa: Literature issues and challenges. Paper Presented to nthe Clobal Corporate Governance Forum 15 June 2003. pp 1-34

Okike E.N.M. (2007) "Corporate Governance in Nigeria: The Status quo", Corporate Governance (15) 2 173-193

Okuaru (2006), "EFCC raises Alarm over Money laundering" The Guardian March 2

Olusa M. (2007), Corporate Governance Vs Cadbury Nigeria

Oyejide T.A. \& Soyibo A. (2001). A paper presented at the conference on Corporate Governance Accra Ghana 29-30 January 2001

Pan- African Consultative Forum on Corporate Governance (2001).

Reed, D. (2002) "Corporate Governance Reforms in Developing Countries". Journal of Business Ethics 37,223-247

Roe,M. J. (2003), Political determinations of corporate governance: Political context, corporate impact, Oxford, U.K. Oxford University Press.

Rosser A.(2003), 'Coalitions, convergence and corporate governance reform in Indonesia'. Third World Quarterly 24 (2) 319-338

Russouw G.J (2005), Business Ethics and Corporate Governance in Africa, Business \&Socety 44 (10) $94-106$

Saliu H.A. \& Aremu F.A (2004), 'A critical Analysis of the Anti- Corruption Crusade in Nigeria' Political Science Review 3 (5).

Sanda, Mikailu \& Garba (2005), Corporate governance mechanism and firm financial performance in Nigeria. AERC Research Paper 149, African Economic Research Consortium, Nairobi. Kenya.

Sanusi, J.O. (2003) Embracing good cooperate governance practices in Nigeria. Keynote address by governor of the Central Bank of Nigeria at the $19^{\text {th }}$ Annual Directors' Seminar organized by the Financial Institutions Training Centre in Abuja, Nigeria on June 17, 2003

Sanusi, L.S. (2010) 'Reporting, Regulation and Risks management: Repositioning the Nigerian Financial System" Keynote Address by governor of the Central Bank of Nigeria Lagos Nigeria. January 7, 2010.

Security and Exchange Commission- SEC (2003), Code of Corporate Governance in Nigeria.

Scott, D.H. (2007), Strengthening the governance and performance of state-owned financial institutions. Policy research Working Paper 4321, August 2007, The World Bank.

Soludo C.C. (2004), Consolidating the Nigerian banking industry to meet the development challenges of the $21^{\text {st }}$ century. Address by governor of the central bank of Nigeria at the special meeting of the Bankers' Committee in Abuja on July 6, 2004

Thisday (2009), Nigeria: Banking Crisis - NDIC admits Regulatory Lapses October 30, 2009

Tomori O. (2010), "Whither Nigeria? Or Whither" University of Lagos Convocation lecture delivered on January 13 at the Main Auditorium, University of Lagos, Akoka, Lagos, Nigeria.

Tukur, M. (1999), Leadership and Governance in Nigeria: The Relevance of values. London: Hudahuba/ Hodder \& Stoughton.

Ugoji \& Isele (2009) "Stress management \& corporate governance In Nigerian Organizations" European Journal of Scientific Research. 27 (3) 472-478

Vaughan M. \& Ryan L.V. (2006), Corporate governance in South Africa: A bellwether for the Continent?' Corporate Governance 14 (5) 504-512

Vinten G. (1998), Corporate governance: An International state of the art. Managerial Auditing Journal 13(7) 419-431

Vinten G. (2002) The Corporate governance lessons of Enron, corporate governance 2(4) 4-9

Visser, W. (2006), Revisiting Carroll's CSR Pyramid, in: Predersen E.R. \& Huniche, M (eds), Corporate Citizenship in Developing Countries, The Copenhagen Centre.

Wieland (2005) "Corporate Governance,, Values management and Standards: A European Perspective", Business and society 44, 1: 74-96

Wixley, T\& Everingham G. Corporate governance ( $\left.2^{\text {nd }} e d\right)$, Claremonth, South Africa: Siber Ink 
Wilson, I. (2006), "Regulatory and Institutional Challenges of Corporate Governance in Nigeria Post Banking Consolidation." Economic Indicators Nigerian Economic Summit Group (NESG) April June 2006

World Bank (1999) Corporate Governance: A Framework for implementation (Overview), World Bank (2009) World Development Report. World Bank Group

Yakaisai A.G.A (2001), "Corporate Governance in a Third World Country with particular reference to Nigeria”. Corporate Governance 9 (3) 238-253.

Yinusa, M.A \& Adeoye, M.N. (2006), Religious value: A Panacea to corruption in Nigeria" Ijagun journal of social and management Science 1 (1) 1-14

Zekeri M. (2008) "Church is the key to corruption-free Nigeria" reported by Ogunlade A. in The Nation on May 4, 2008. 
